\title{
Lungnaígræðslur á Íslendingum
}

\author{
Sif Hansdóttir ${ }^{\star 1}$ læknir, Hrönn Harðardóttir ${ }^{\star 1,2}$ læknir, Óskar Einarsson ${ }^{1}$ læknir, Stella Kemp Hrafnkelsdóttir ${ }^{1}$ hjúkrunarfræðingur, \\ Gunnar Guðmundsson ${ }^{1,2}$ læknir
}

\section{ÁGRIP}

Inngangur: Lungnaígræðsla er valkostur við meðferð á langt gengnum lungnasjúkdómum, öđrum en krabbameinum, pegar lísslíkur eru mjög skertar og lífsgæð̋ léleg, prátt fyrir bestu mögulegu meðferð. Í flestum tilvikum batna lungnapróf og heilsutengd lífsgæðð mikið viơ lungnaígræðslu. Sýkingar og stíflumyndandi berkjungabólga, einnig kallað langvinn höfnun, eru algengustu fylgikvillarnir eftir lungnaígræðslu.

Efniviður og aðferðir: Hér er sagt frá íslenskum sjúklingum sem farið hafa i lungnaígræðslu frá febrúar 1988 til janúar 2015. Gagnagrunnur var unninn afturskyggnt úr sjúkraskrám. Safnað̃ var upplýsingum um bakgrunn sjúklinga, ígræðsluaðgerð, ónæmisbælingu og hafnanir, fylgikvilla og lifun. Niðurstöđur: Alls hefur verið gerð 21 lungnaígræðsla á 20 einstaklingum en einn sjúklingur hefur tvisvar farið í aðgerð. Um var að ræða 9 konur og 11 karla og meðalaldur við ígræðslu var 45 ár (20-61 ár). Flestar aðgerðirnar hafa verið gerðar á Sahlgrenska-sjúkrahúsinu í Gautaborg. Flestir fengu ígrædd bæð̇ lungu. Langvinn lungnateppa var algengasta ábendingin. Algengustu fylgikvillar eftir lungnaígræơslu voru hafnanir og sýkingar. Átta af 20 sjúklingum hafa fengið bráđahöfnun og helmingur sjúklinga langvinna höfnun. Alls eru 6 af 20 sjúklingum látnir, af peim létust prír vegna langvinnrar höfnunar á ígræddu líffæri. Mið̃gildi lifunar er 8,5 ár. Fimm ára lifun er $74 \%$.

Ályktanir: Lungnaígræðslur á Íslendingum eru nú framkvæmdar á Sahlgrenskasjúkrahúsinu i Gautaborg en eftirfylgni er á vegum sérhæfðra lungnalækna á Landspítala. Fylgikvillar og lifun íslenskra sjúklinga er sambærilegt við bað sem gerist á stærri stofnunum. Náin samskipti og samstarf við stofnunina par sem ígræðsla fer fram er lykilatriði.
Fyrirspurnir: Gunnar Guðmundsson ggudmund@landspitali.is

Greinin barst 18. desember 2015, sambykkt til birtingar

15. mars 2016.

\section{Inngangur}

Lungnaígræðslur hófust uppúr 1960, en árangur var lélegur framan af. ${ }^{1}$ Eftir 1980 komu öflugri ónæmisbælandi lyf til sögunnar og aðgerðum fjölgaði. Árangur hefur farið batnandi upp frá pví og lungnaígræðslur hafa náð að festa sig í sessi sem valkostur í völdum tilfellum við ýmsum lungnakvillum. ${ }^{2-4}$ Peim er beitt við margvíslegum lungnasjúkdómum, svo sem langvinnum lungnateppusjúkdómum, bandvefsmyndandi sjúkdómum, sjúkdómum sem valda prálátum sýkingum eins og slímseigjusjúkdómi (cystic fibrosis) og lungnaæðasjúkdómum. Hægt er að græða í bæði hjarta og lungu, annað lunga eða bæði lungu eftir sjúkdómsgerð. ${ }^{2-4}$ Hjá sjúklingum með mikla skerðingu á starfsgetu og takmarkaðar lífslíkur vegna lungnasjúkdóma getur lungnaígræðsla aukið bæði lífslíkur og lífsgæði.

Almennt er ábending fyrir lungnaígræðslu versnandi lungnastarfsemi vegna sjúkdóms sem engin meðferð er til við eða hámarkslyfjameðferð dugar ekki til að viðhalda lungnastarfsemi. ${ }^{2-4}$ Um er að ræða sjúkdóma aðra en krabbamein. Ákvörðunin um hvenær á að setja sjúkling á biðlista fyrir lungnaígræðslu er mismunandi eftir sjúkdómum. Aðalatriðið er að lungnaígræðsla sé líkleg til að lengja líf sjúklings. Pannig parf að vera meiri áhætta fólgin í pví að halda áfram meðferð heldur en að fara í lungnaígræðslu. Almennt er hugað að lungnaígræðslu pegar tveggja til priggja ára lífslíkur eru minni en 50\% og skerðing á lífsfærni mikil (færnimat samkvæmt NYHA (New York Heart Association scale) á stigi III eða IV). Á flestum stöðum er langvinn lungnateppa (LLT) algengasta ástæða lungnaígræðslu. Algengt er að nota svokallaðan BODE-kvarða (Body mass index, Airflow Obstruction, Dyspnea og Exercise capacity) til að meta pörf fyrir lungnaígræðslu hjá sjúklingum með LLT. Í honum er mat fyrir líkamspyngdarstuðul, lungnateppu, mæði og áreynslugetu. Ef heildarstigafjöldi er hærri en 5 er ábending fyrir að setja sjúkling í uppvinnslu fyrir lungnaígræðslu og meta hann heildrænt. Við mat á bandvefsmyndandi lungnasjúkdómum er stuðst við gerð breytinga á tölvusneiðmyndum og lækkun á lungnaprófum yfir 6 mánaða tímabil. Að auki er stuðst við aðrar mælingar á lungnastarfsemi og lækkun á súrefnismettun við áreynslu. Í slímseigjusjúkdómi er hugað að lungnaígræðslu pegar gildi FEV1 (forced expiratory volume in 1 second, kröftugt fráblástursrúmmál á fyrstu sekúndu) er komið undir 30\% af áætluðu gildi og versnanir eru tíðar vegna sýkinga. Einnig ef til staðar eru viðvarandi loftbrjóst eða blóðhósti. Í lungnaháprýstingi er hugað að lungnaígræðslu við hraðan gang sjúkdóms og mikla skerðingu á lífsfærni prátt fyrir hámarkslyfjameðferð. ${ }^{2-4}$

Í upphafi var hjarta- og lungnaígræðsla samtímis vegna flókinna hjartagalla með Eisenmenger-heilkenni eða við mjög langvinna lungnasjúkdóma sem höfðu valdið skerðingu á hjartastarfsemi algengasta aðgerðin. Á síðustu misserum hefur pessum aðgerðum fækkað vegna bættrar greiningar og meðferðar pessara sjúkdóma á byrjunarstigum. ${ }^{5}$ Í dag er lungnaígræðsla beggja vegna algengasta tegund aðgerðar.

Eftir lungnaígræðslu hefst ævilöng meðferð með lyfjum sem draga úr líkum á höfnun og pessir sjúklingar eru undir nákvæmu eftirliti ævina á enda. Par sem lungun eru stöðugt útsett fyrir ónæmisvökum og 


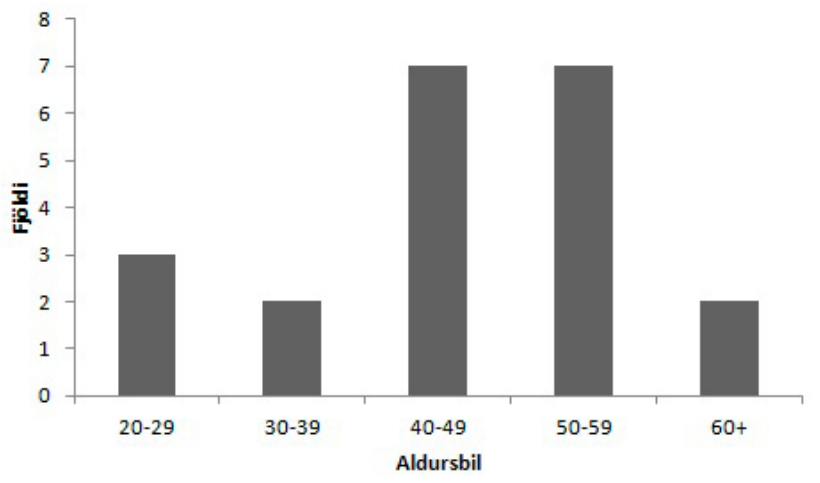

Mynd 1. Aldur við ígræðslu.

sýklum í umhverfinu parfnast lungnapegar öflugri ónæmisbælingar en aðrir líffærapegar. Pví miður eru fylgikvillar algengir og setja hömlur á langtímavirkni ígræddra lungna sem og á lífsgæði og lifun sjúklingsins. ${ }^{6-9}$ Lifun eftir lungnaígræðslur er pví almennt skemmri en eftir ígræðslur á öðrum líffærum.

Algengasti fylgikvillinn eftir lungnaígræðslu er höfnun, bráð og langvinn. Bráðri höfnun valda bólguviðbrögð vegna T-frumumiðlaðrar svörunar við ókunnugum vefjaflokkagenum (major histocompatibility complex, MHC). ${ }^{8}$ Grunur um bráđahöfnun vaknar oft á klínískum grunni en greiningin byggist á sérstöku vefjafræðiútliti á vefjasýni úr lungnavefnum. Til er alpjóðlegur staðall par sem vefjasýnin eru metin eftir vefjafræðilegu útliti peirra og höfnunargráða frá 1 til 4 ákvörðuð eftir pví hversu mikil höfnunin er. ${ }^{9}$

Langvinn höfnun er samheiti yfir ástand par sem viðvarandi lækkun (um $>20 \%$ ) verður á fráblástursgildum frá bestu gildum sjúklings eftir ígræðslu. Greiningin er klínísk og byggist á öndunarprófum eftir að búið er útiloka sýkingar, bráðahöfnun og annað sem getur valdið versnun á klínísku ástandi. Oftast er um að ræða teppumynd á fráblástursprófum en herpumynd getur einnig komið fram. Áhættupættir eru fjöldamargir og má par nefna bráða frumutengda höfnun, myndun gjafa-sérhæfðra mótefna gegn HLA-flokkum, vélindabakflæði með ásvelgingu og öndunarfærasýkingar af völdum veira. ${ }^{6,7,9}$

Fyrsta lungnaígræðslan á Íslendingi var gerð pann 2. febrúar árið 1988. ${ }^{10}$ Í pessari grein verður sagt frá lungnaígræðslum á Íslendingum frá peim tíma og til 1. janúar 2015. Fjallað er um ábendingar, ónæmisbælingu, hafnanir og aðra fylgikvilla og árangur.

\section{Efniviður og aðferðir}

Pýði rannsóknarinnar voru allir íslenskir sjúklingar sem farið hafa í lungnaígræðslu, samtals 20 manns. Gagnagrunnur var

Tafla I. Framkvæmd lungnaígræðsIna á Íslendingum.

\begin{tabular}{llc}
\hline Tímabil & \multicolumn{1}{c}{ Hvar framkvæmd } & Fjöldi ígræðslna \\
\hline 1988-1992 & Harefield Hospital, London, Bretland & 2 \\
\hline 1994-1996 & Sahlgrenska, Gautaborg, Svípjóð & 4 \\
\hline 2003-2007 & Rigshospitalet, Kaupmannahöfn, Danmörk & 4 \\
\hline $2008-2015$ & Sahlgrenska, Gautaborg, Svípjóð & 11
\end{tabular}

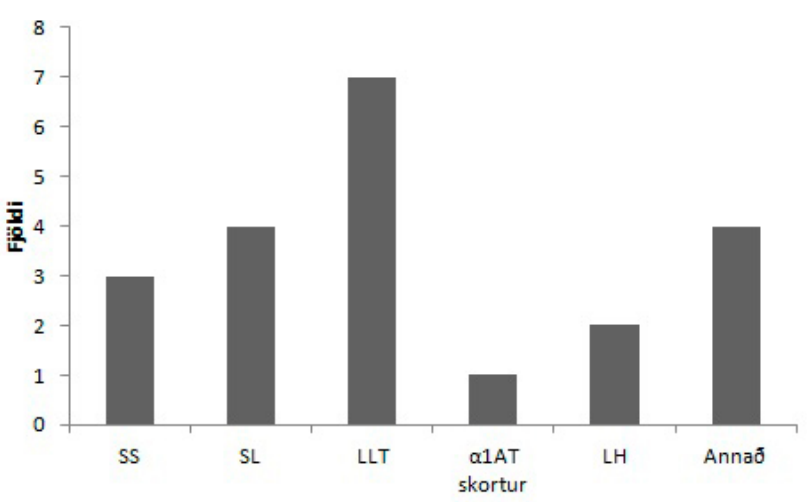

Mynd 2. Ábendingar fyrir ígræðslu. SS; slímseigjusjúkdómur, SL; sjálfvakin lungnatrefjun, LLT; langvinn lungnateppa, AT; antitrypsin, LH; lungnaslagæðaháprýstingur.

gerður afturskyggnt og klínískar upplýsingar fengnar úr sjúkraskrám (Sögukerfi Landspítala).

Eftirfarandi breytur voru skoðaðar: i) Bakgrunnsupplýsingar; kyn, aldur á aðgerðardegi og ástæða fyrir ígræðslu. ii) Upplýsingar um aðgerð; staðsetning ígræðslu og tegund ígræðslu (eitt lunga, tvö lungu eða hjarta- og lungu). iii) Ónæmisbælandi lyfjameðferð eftir ígræðslu. iv) Hafnanir; bráðahöfnun samkvæmt vefjagreiningu eða langvinn höfnun, skilgreind sem FEV1 <80\% af grunngildi (meðaltal tveggja bestu FEV1-mælinga 6-12 mánuðum eftir ígræðslu). v) Sýkingar frá árinu 2006; bakteríusýkingar og sveppasýkingar samkvæmt. ræktunum, veirusýkingar samkvæmt ræktunum eða PCR (Polymerase Chain Reaction) fyrir öndunarfæraveirur og CMV (Cytomegalovirus) samkvæmt. PCR á sermi $(\geq 500$ eintök). vi) Aðrir algengir fylgikvillar; nýrnastarfsemi og illkynja sjúkdómar. vii) Dánardagur.

Gögn úr sjúkraskýrslum voru skráð í forritið Microsoft Office Excel og lýsandi tölfræði unnin úr pví. Lifunargreining (Kaplan Meier) var reiknuð út með tölfræðiforritinu $\mathrm{R}$ par sem tekið var tillit til pess sjúklings sem hafði farið í endurígræðslu. Eftirfylgd sjúklings sem fór í endurígræðslu var skert á peirri stundu sem endurígræðslan fór fram og endurræst frá núlli með nýrri færslu á peim tímapunkti. Aðstoð við tölfræðiúrvinnslu var fengin hjá Sigrúnu Helgu Lund lektor í líftölfræði, Miðstöð lýðheilsuvísinda Háskóla Íslands.

\section{Niðurstöður}

Alls hafa 20 sjúklingar farið í lungnaígræðslu og af peim fengu tveir einnig hjartaígræðslu. Um var að ræða 9 (45\%) konur og 11 (55\%) karla. Meðalaldur við ígræðslu var 45 ár (aldursbil 20-61 ár) og er aldursdreifing sýnd á mynd 1. Ábendingar fyrir ígræðslu eru sýndar á mynd 2 og var langvinn lungnateppa (LLT) algengasta ábendingin.

Í töflu I er sýnt hvar ígræðslurnar voru gerðar og á hvaða tímabili. Flestar voru ígræðslurnar framkvæmdar á Sahlgrenskasjúkrahúsinu í Gautaborg og rúmlega helmingur aðgerða fór fram á árunum 2008 til 2015. Mynd 3 sýnir fjölda ígræðslna eftir árum og voru langflestar aðgerðir gerðar árið 2012. Mynd 4 sýnir tegund 


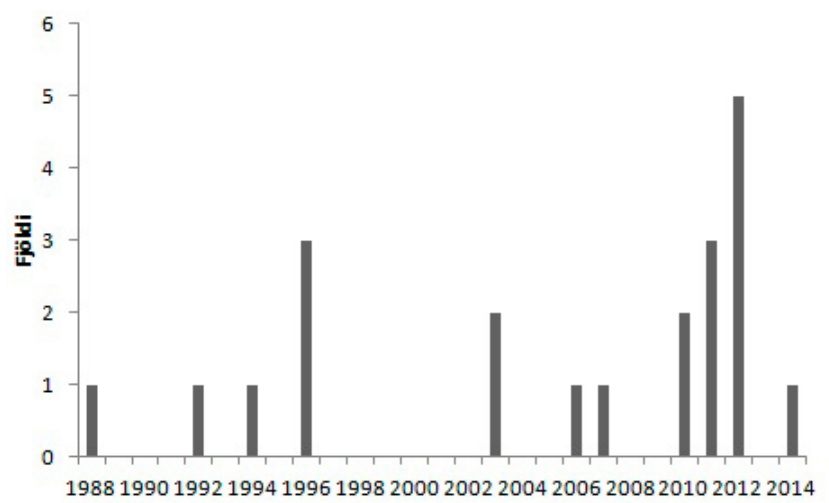

Mynd 3. Fjöldi ígræð̌slna eftir árum.

Tafla II. Ónæmisbælandi Iyfjameðferð.

\begin{tabular}{lc}
\hline Ónæmisbælandi lyf & Fjöldi sjúklinga \\
\hline Prednisólon & 20 \\
\hline Cyclosporín & 15 \\
\hline Tacrolimus & 5 \\
\hline Sirolímus & 1 \\
\hline Everolimus & 4 \\
\hline Azathioprín & 5 \\
\hline Mycofenolat mofetil & 9 \\
\hline Azitromycín & $9^{*}$ \\
\hline
\end{tabular}

*Sýklalyf með áhrif á ónæmiskerfið

ígræðslu, pað er hjarta- og lungu, eitt lunga eða bæði lungu, en flestir fengu ígrædd bæði lungu.

Ónæmisbæling með lyfjum hefst strax eftir aðgerðina og er ævilöng. Fyrri hluta rannsóknartímans var algengast að nota prednisólon, cyclosporín og azathioprín saman en síðastliðin ár hefur azathioprin horfið en mykófenolat mofetil komið í staðinn. Pá er azithromycin mikið notað nú við langvinnri höfnun. Tafla II sýnir hvaða ónæmisbælandi lyf hafa verið notuð hjá pessum sjúklingum.

Helstu fylgikvillar lungnaígræðslna eru sýndir í töflum III og IV. Bráðahöfnun, staðfest með vefjasýni, greindist hjá 8 sjúklingum og langvinn höfnun hjá 10 sjúklingum. Sjö sjúklingar með bráðahöfnun greindust í kjölfarið með langvinna höfnun og af peim eru prír látnir. Sjúklingar með ígrædd lungu parfnast mikillar ónæmisbælingar (samanborið við önnur ígrædd líffæri) og eins og sjá má í töflu IV eru veiru-, bakteríu- og sveppasýkingar algengar hjá pessum sjúklingahópi. Aðrir algengir fylgikvillar voru nýrnabilun og húðkrabbamein sem kom fram hjá peim sem voru með lengri lifun. Einn sjúklingur fór í nýrnaígræðslu.

Alls eru 6 af 20 sjúklingum látnir. Einn sjúklingur lést vegna frumgræðlingsbilunar premur dögum eftir aðgerð, prír létust vegna langvinnrar höfnunar á ígræddu líffæri og einn úr kransæðasjúkdómi. Einn sjúklingur lést vegna herslismeins sem var undirliggjandi sjúkdómur sjúklings. Lifun er sýnd á mynd 5 . Lifun eftir eitt ár var 95,2\%, eftir 5 ár 74\% og eftir 10 ár 42,3\%. Mið-

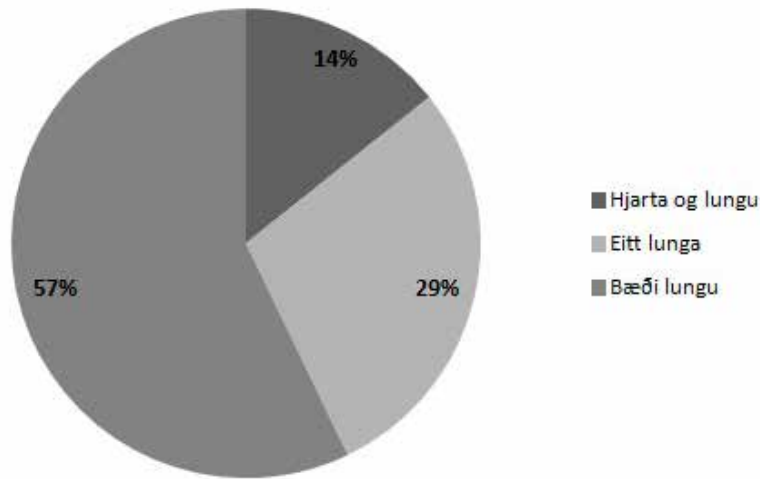

Mynd 4. Tegund ígræðslna.

gildi lifunar allra sjúklinga er 8,5 ár. Tveir sjúklingar sem fengu hjarta- og lungnaígræðslu hafa lifað í yfir 20 ár og einn sjúklingur sem fékk ígrætt eitt lunga er á lífi eftir 19 ár.

\section{Umræða}

Lungnaígræðsla er meðferðarúrræði fyrir takmarkaðan hóp lungnasjúklinga með alvarlegan sjúkdóm á lokastigi að prautreyndum öðrum meðferðarmöguleikum. Alls fengu 20 íslenskir sjúklingar lungnaígræðslu á árunum 1988 til ársbyrjunar 2015.

Alpjóðlegu hjarta- og lungnaígræðslusamtökin (International Society for Heart and Lung Transplantation, ISHLT) halda úti nákvæmum gagnagrunni með upplýsingum um alla sjúklinga í heiminum sem fara í lungnaígræðslu eða hjarta- og lungnaígræðslu. ${ }^{5,11}$ Við berum hér okkar pýði saman við skýrslu ISHLT frá 2014. ${ }^{5,11}$ Samanburðurinn er gerður með peim fyrirvara að okkar sjúklingahópur er fámennur og að flestar ígræðslur fóru fram árið 2012. Hlutfallslega fleiri íslenskir karlmenn (55\%) en konur fóru í lungnaígræðslu og er pað í samræmi við tölur frá ISHLT.,11

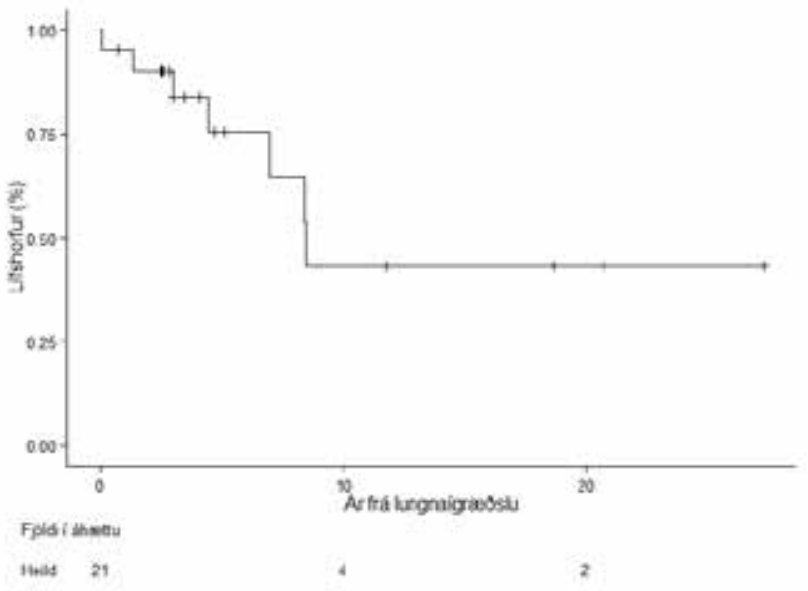

Mynd 5. Lífshorfur (Kaplan-Meier-kúrfa) 20 íslenskra sjúklinga sem fóru ílungnaigræðslu á árunum 1988-2014. Lifun eftir eitt, 5 og 10 ár var 95,2\%, 74\% og 42,3\%, miðgildi lifunar var 8,5 ár. 
Tafla III. Algengir fylgikvillar lungnaígræðsına.

\begin{tabular}{ll}
\hline Fylgikvillar & Fjöldi sjúklinga \\
\hline Líffærahöfnun & \\
\hline Bráðahöfnun (staðfest með vefjasýni) & 8 \\
\hline Á fyrsta ári eftir ígræðslu & 4 \\
\hline Meira en einu ári eftir ígræðslu & 4 \\
\hline Langvinn höfnun & 10 \\
\hline Mótefnaskortur (lgG) & 3 \\
\hline Nýrnabilun & 10 \\
\hline Stig 2, GSH >60-89 mL/mín/1,73 m2 & 8 \\
\hline Stig 3, GSH 30-59 mL/mín/1,73 m2 & 1 \\
\hline Stig 4, GSH 15-29 mL/mín/1,73 m2 & 1 \\
\hline Stig 5, GSH $<15 \mathrm{~mL} / \mathrm{mín} / 1,73 \mathrm{~m} 2$ & 3 \\
\hline Krabbamein & 1 \\
\hline Húðkrabbamein & \\
\hline Eitilfrumukrabbamein & \\
\hline GSH: gaukulsíunarhraði &
\end{tabular}

Algengasta ábending hjá íslenskum sjúklingum fyrir lungnaígræðslu var LLT (33,3\%), sem einnig er í samræmi við skýrslu ISHLT par sem 32,6\% ábendinga var LLT.

Algengasta aðgerðin var lungnaígræðsla beggja vegna og er pað einnig í samræmi við gagnagrunn ISHLT. Meðalaldur íslenskra sjúklinga var 45 ár við ígræðslu og er pað sambærilegt við alpjóðlegar tölur en eftir 2002 hefur meðalaldur farið hækkandi og er nú um 55 ár. ${ }^{5,11}$

Eins og annars staðar eru fylgikvillar eftir lungnaígræðslur algengir hjá íslenskum sjúklingum. Bráðahöfnun átti sér stað hjá 8 af 20 sjúklingum en prátt fyrir próun í gjöf ónæmisbælandi meðferðar við ígræðslu er petta mikið vandamál eftir lungnaígræðslu og allt að priðjungur lungnapega fær bráđahöfnun á fyrsta árinu. ${ }^{3,8}$ Einkenni bráðrar höfnunar eru oft lúmsk og skimað er eftir bráðahöfnun með berkjuspeglun einum, premur og 12 mánuðum eftir ígræðslu og ef marktæk versnun verður á öndunarprófum. ${ }^{9}$ Ef lungnapegi finnur fyrir breytingu á almennri líðan eða fær öndunareinkenni án augljósrar skýringar, er mikilvægt að útiloka og meðhöndla bráðahöfnun. Sjúklingar sem fá bráðahöfnun eru í aukinni hættu á að fá langvinna höfnun. Pað er sá fylgikvilli sem er algengastur og hvað erfiðastur viðureignar. ${ }^{6,79}$ Helmingur íslenska pýðisins hefur verið greindur með langvinna höfnun sem er algengasta dánarorsök lungnapega. Langvinn höfnun leiðir til skertra lífsgæða og hjá sumum til dauða.,7,99 Meðferðarúrræði langvinnrar höfnunar eru takmörkuð. ${ }^{6,79}$ Á rannsóknatímabilinu varð frampróun í meðferð langvinnrar höfnunar pegar hafin var meðferð með azitromycíni í lágum skömmtum sem er talið hafa bólguhamlandi áhrif og seinka höfnunarferlinu. ${ }^{12,13}$ Einnig er skipt yfir í nýrri höfnunarlyf sem talin eru hafa meiri bólguhemjandi áhrif. ${ }^{14}$ Í völdum tilvikum má íhuga endurígræðslu.

Sýkingar eru annar algengur fylgikvilli. Lungnaígræðslur greina sig frá öðrum líffæraígræðslum að pví leyti að lungun eru opin fyrir umhverfinu og pví útsettari fyrir sýkingum en önnur ígrædd líffæri. Á síðustu 10 árum voru öndunarfærasýkingar, bæði
Tafla IV. Sýkingar hjá lungnapegum frá árinu 2006 til 2015.

\begin{tabular}{|c|c|c|c|c|}
\hline Sýkill & & $\begin{array}{l}<1 \text { ár frá } \\
\text { ígræðslu }\end{array}$ & $\begin{array}{l}>1 \text { ár frá } \\
\text { ígræòslu }\end{array}$ & Samtals \\
\hline \multicolumn{5}{|l|}{ Bakteríur } \\
\hline & Gram-neikvæðar & & & \\
\hline & $\begin{array}{l}\text { Acinetobacter } \\
\text { baumanni }\end{array}$ & 1 & $1^{*}$ & 2 \\
\hline & Eschericia coli & & 1 & 1 \\
\hline & Klebsiella oxytoca & 1 & & 1 \\
\hline & $\begin{array}{l}\text { Pseudomonas } \\
\text { aeruginosa }\end{array}$ & 1 & 1 & 2 \\
\hline & & 2 & & 2 \\
\hline & $\begin{array}{l}\text { Stenotrophomonas } \\
\text { maltophila }\end{array}$ & & & \\
\hline & $\begin{array}{l}\text { Moraxella } \\
\text { catarrhalis }\end{array}$ & 1 & & 1 \\
\hline & $\begin{array}{l}\text { Enterobacter } \\
\text { cloacae }\end{array}$ & 1 & & 1 \\
\hline & $\begin{array}{l}\text { Bordetella } \\
\text { parapertussis }\end{array}$ & & 1 & 1 \\
\hline & Gram-jákvæðar & & & \\
\hline & Enterococcus sp & & 2 & 1 \\
\hline & Actinomyces & & 1 & 1 \\
\hline Mýkóbakteríur & & 0 & 0 & 0 \\
\hline \multicolumn{5}{|l|}{ Sveppir } \\
\hline & Candida sp. & & 2 & 1 \\
\hline & Aspergillus sp. & 2 & 2 & 4 \\
\hline & $\begin{array}{l}\text { Pneumocystis } \\
\text { jiroveci* }^{\star \star}\end{array}$ & 1 & & 1 \\
\hline \multicolumn{5}{|l|}{ Veirur } \\
\hline & Cytomegalovirus ${ }^{\star \star *}$ & 5 & 1 & 6 \\
\hline & $\begin{array}{l}\text { Öndunarfæraveirur } \\
\text { (PCR) }\end{array}$ & 1 & 6 & 7 \\
\hline
\end{tabular}

* Sýking í kinnholum

* Ađur Pneumocystis carini

** Skilgreint sem $\geq-500$ eintök á PCR á sermi (upplýsingar fyrir 14 sjúklinga).

veiru- og bakteríusýkingar, algengustu sýkingar hjá íslenskum lungnapegum. Рað er svipað og í öðrum rannsóknum. Rannsókn frá Suður-Kóreu sýndi að fyrsta mánuðinn eftir ígræðslu voru blóðsýkingar tengdar leggjum algengustu bakteríusýkingarnar. ${ }^{15}$ Eftir fyrstu 6 mánuðina voru lungnabólgur algengustu bakteríusýkingarnar. Cytómegalóveirusýking var algengasta veirusýkingin fyrstu 6 mánuðina eftir ígræðslu en eftir pað voru sýkingar af völdum öndunarfæraveira algengastar.

Miðgildi lifunar sjúklinga eftir lungnaígræðslu er samkvæmt skýrslu alpjóðlegu hjarta- og lungnaígræðslusamtakanna 5,7 ár og eins, 5, og 10 ára lifun $80 \%, 53 \%$ og 32\%. 5,11 Samanburður við íslenska pýðið takmarkast af smæð pýðisins en lifunartölur hjá okkar sjúklingahópi voru ívið betri en pessar tölur frá ISHLT. Rétt er að benda á að tveir íslenskir sjúklingar hafa lifað mjög lengi og að langflestar ígræðslur á íslenskum sjúklingum voru gerðar árið 2012 og pví ekki kominn langur eftirfylgdartími fyrir pá. 
Okkar tölur eru sambærilegar lifunartölum sem Svíar hafa birt á lifun 342 sjúklinga eftir lungnaígræslu vegna LLT par sem eins, 5, og 10 ára lifun var 85\%, 66\% og 43\%. ${ }^{16}$ Ef litið er til samantektar lungnaígræðslusjúklinga í Danmörku frá árunum 1992 til 2003 var sýnt fram á eins, 5, og 10 ára lifun upp á 81\%,63\% og 36\%. Í peim hópi voru 21 af 362 lungnapegum sem höfu fengið ígrædd bæði hjarta og lungu. ${ }^{17}$ Peir tveir Íslendingar sem lifað hafa lengst eftir aðgerð fóru báðir í hjarta- og lungnaígræðslu vegna meðfædds hjartagalla sem olli lungnaháprýstingi. Langtímalifun eftir slíkar aðgerðir er oft betri en eftir lungnaígræðslu sem gerð er vegna lungnasjúkdóms par sem um er að ræða yngri sjúklinga með færri fylgisjúkdóma. Í dag væri að jafnaði gert við pessa hjartagalla með skurðaðgerð snemma á ævinni og ekki kæmi til lungnaígræðslu. Sjúklingum með langvinna lungnateppu hefur fjölgað mjög á Íslandi undanfarin ár og er rétt að farið sé yfir ábendingar fyrir lungnaígræðslu hjá pessum sjúklingum pegar sjúkdómurinn er farinn að valda mikilli skerðingu á lífsgæðum. ${ }^{3}$ Almennt er mikilvægt að slík uppvinnsla fari ekki fram of seint, pannig að sjúkdómurinn sé ekki of langt genginn og sjúklingur sé orðinn of veikur fyrir aðgerð eða eigi skammt eftir ólifað.,2,3,4

Vel skipulagt og reglulegt eftirlit er nauðsynlegt hjá sjúklingum sem hafa farið í lungnaígræðslur. Mikilvægt er að eftirlitið sé í höndum lækna með sérfræðikunnáttu á sviði lungnaígræðslna. Á undanförnum árum hefur verið myndaður pverfaglegur hópur fagaðila á Landspítala og Reykjalundi sem koma að málefnum íslenskra lungnaígræðslusjúklinga ásamt sérhæfðri göngudeild.
Til að tryggja frampróun lungnaígræðslna parf að koma til aukið framboð á líffærum og betri meðferð við langvinnri höfnun. ${ }^{18,19}$ Stöðugt er unnið að próun nýrra ónæmisbælandi lyfja og skurðtækni verður sífellt betri. Til pess að bæta árangur eftir lungnaígræðslu og fjölga mögulegum gjafalungum, er nýlega farið að meðhöndla gjafalungu utan líkamans í allt að sólarhring fyrir ígræðslu. ${ }^{20,21}$ Pá eru lungun sett í öndunarvél og fá pannig súrefni. Í gegnum æðakerfi peirra eru settar næringarlausnir, sýklalyf og bólgueyðandi lyf. Pannig er hægt að minnka bjúg, bólgu og sýkingar í gjafalunganu fyrir ígræðslu. Á pann hátt er hægt að nota lungu sem eru í verra ástandi en áður var gert. Líta verður svo á að um sé að ræða meðferð á tilraunastigi. Farið er að nota pessa meðferð í Gautaborg.

Árangur lungnaígræðslna er betri hjá stofnunum par sem margar ígræðsluaðgerðir eru framkvæmdar. Pví er mikilvægt fyrir okkur Íslendinga að halda áfram samvinnu við bestu stofnanir á Norðurlöndum til að tryggja að lungnaígræðsla geti verið meðferðarmöguleiki fyrir íslenska lungnasjúklinga.

\section{Pakkir}

Starfsmönnum Landspítala og Reykjalundar er pakkað kærlega fyrir aðstoð við lungnaígræðslusjúklinga allt frá pví lungnaígræðslur hófust. Sigrúnu Helgu Lund lektor í líftölfræði, Miðstöð lýðheilsuvísinda HÍ, er pakkað kærlega fyrir aðstoð við tölfræðiúrvinnslu.

\section{Heimildir}

1. Hardy JD, Eraslan S, Webb WR. Transplantation of the lung. Ann Surg 1964; 160: 440-8.

2. Rampolla R. Lung transplantation: an overview of candidacy and outcomes. Ochsner J 2014; 14: 641-8.

3. Zeriouh M, Mohite PN, Sabashnikov A, Zych B, Patil $\mathrm{NP}$, Garcia-Saez D, et al. Lung transplantation in chronic obstructive pulmonary disease: long-term survival, freedom from bronchiolitis obliterans syndrome, and factors influencing outcome. Clin Transplant 2015; 29: 383-92.

4. Orens JB, Estenne M, Arcasoy S, Conte JV, Corris P, Egan $\mathrm{JJ}$, et al. International guidelines for the selection of lung transplant candidates: 2006 update-a consensus report from the Pulmonary Scientific Council of the International Society for Heart and Lung Transplantation. J Heart Lung Transplant 2006; 25: 745-55.

5. Yusen RD, Edwards LB, Kucheryavaya AY, Benden C, Dipchand AI, Dobbels F, et al. The registry of the International Society for Heart and Lung Transplantation: thirty-first adult lung and heart-lung transplant report--2014; focus theme: retransplantation. J Heart Lung Transplant 2014; 33: 1009-24.

6. Todd JL, Palmer SM. Bronchiolitis obliterans syndrome. The final frontier for lung transplantation. Chest 2011; 140: 502-8.

7. Weigt SS, Wallace WD, Derhovanessian A, Saggar R, Saggar R, Lynch JP, et al. Chronic allograft rejection: epidemiology, diagnosis, pathogenesis, and treatment. Semin Respir Crit Care Med 2010; 31: 189-207.
8. Martinu T, Pavlisko EN, Chen DF, Palmer SM. Acute allograft rejection: cellular and humoral processes. Clin Chest Med 2011; 32: 295-310.

9. Meyer KC, Raghu G, Verleden GM, Corris PA, Aurora $\mathrm{P}$, Wilson KC, et al. ISHLT/ATS/ERS BOS Task Force Committee; ISHLT/ATS/ERS BOS Task Force Committee. An international ISHLT/ATS/ERS clinical practice guideline: diagnosis and management of bronchiolitis obliterans syndrome. Eur Respir J 2014; 44: 1479-503.

10. Guðmundsson G. Lungnaígræðslur. Læknablaðið 2000; 86: 587-90.

11. Stehlik J, Hosenpud JD, Edwards LB, Hertz MI, Mehra MR; International Society for Heart and Lung Transplantation. ISHLT International Registry for Heart and Lung Transplantation--into the fourth decade, from strength to strength. J Heart Lung Transplant 2013; 32: 941-50.

12. Vos R, Vanaudenaerde BM, Verleden SE, Ruttens D, Vaneylen A, van Raemdonck DE, et al. Anti-inflammatory and immunomodulatory properties of azithromycin involved in treatment and prevention of chronic lung allograft rejection. Transplantation 2012; 94: 101-9.

13. Kingah PL, Muma G, Soubani A. Azithromycin improves lung function in patients with post-lung transplant bronchiolitis obliterans syndrome: a meta-analysis. Clin Transplant 2014; 28: 906-10.

14. Scheffert JL, Raza K. Immunosuppression in lung transplantation. J Thorac Dis 2014; 6: 1039-53.
15. Yun JH, Lee SO, Jo KW, Choi SH, Lee J, Chae EJ, et al. Infections after lung transplantation: time of occurrence, sites, and microbiologic etiologies. Korean J Intern Med 2015; 30: 506-14.

16. Tanash HA, Riise GC, Ekström MP, Hansson L, Piitulainen E. Survival benefit of lung transplantation for chronic obstructive pulmoary disease in Sweden. Ann Thorac Surg 2014; 98: 1930-5.

17. Burton CM, Milman N, Carlsen J, Arendrup H, Eliasen $\mathrm{K}$, Andersen $\mathrm{CB}$, et al The Copenhagen National Lung Transplant Group: survival after single lung, double lung, and heart-lung transplantation. J Heart Lung Translant 2005; $24: 1834-43$

18. Nathan SD. The future of lung transplantation. Chest; 147 309-16.

19. Rúnarsdóttir K, Ólafsson K, Arnarsson Á Viðhorf Íslendinga til ætlaðs sampykkis við líffæragjafir. Læknablaðið 2014; 100: 522-5.

20. Popov AF, Sabashnikov A, Patil NP, Zeriouh M, Mohit $\mathrm{PN}, \mathrm{Zych} \mathrm{B}$, et al. Ex vivo lung perfusion - state of the art in lung donor pool expansion. Med Sci Monit Basic Res 2015; 21: 9-14.

21. Machuca TN, Cypel M. Ex vivo lung perfusion. J Thorac Dis 2014; 6: 1054-62. 
ENGLISH SUMMARY

\section{Lung Transplantation in Icelanders}

Sif Hansdottir, Hronn Hardardottir, Óskar Einarsson, Stella Kemp Hrafnkelsdóttir, Gunnar Gudmundsson

Introduction: Lung transplantation is a treatment option for end-stage lung diseases, excluding lung cancer, when life expectancy is short and quality of life is poor. In most instances pulmonary function and quality of life improves after lung transplantation. Infections and rejection are the most common complications and limit the feasibility of lung transplantation.

Materials and methods: Retrospective analysis of lung transplantations performed on Icelanders from February 1988 to January 2015. Clinical information was obtained from medical records and a database was created. Information on demographics, underlying lung disease, type of transplantation, immunosuppression, rejection and other complications was collected.

Results: A total of 21 lung transplantations were performed, one of which was a retransplantation. There were 9 females and 11 males and the mean age was 45 years (20-61 years). Most of the operations were done at the Sahlgrenska hospital in Gothenburg. Bilateral lung transplantion was the most common operation. COPD was the most common indication. Rejection and infections were the most common complications. Eight of 20 patients have had acute rejection and half of the patients chronic rejection. Six of 20 patients are deceased, three died from chronic rejection. Median survival is 8,5 years. Five-year survival is $74 \%$.

Conclusions: Lung transplantations are currently performed at the Sahlgrenska hospital in Gothenburg but follow-up is in the hands of specialized pulmonologists in Iceland. Complications and survival for Icelandic patients is similar to larger centers. Close cooperation with the transplanting center is essential. 